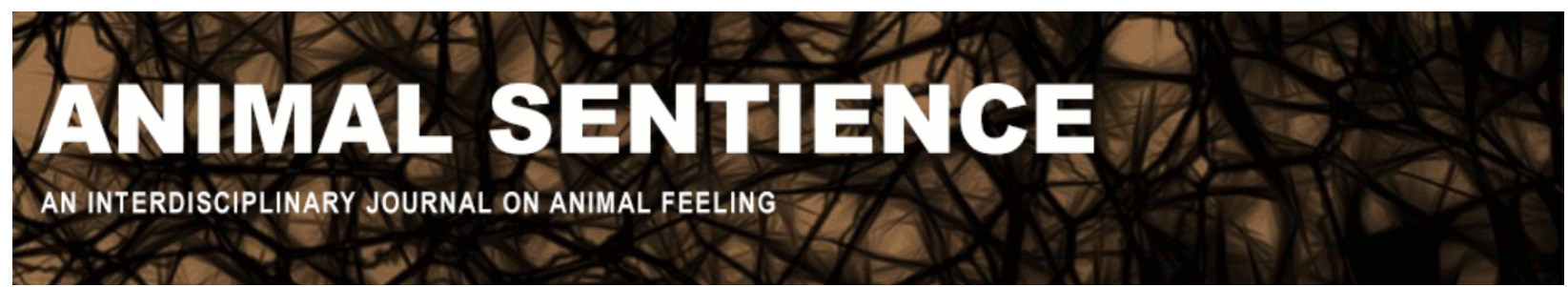

Dinets, Vladimir (2016) No cortex, no cry. Animal Sentience 3(7)

DOI: 10.51291/2377-7478.1027

Date of submission: 2015-09-22

Date of acceptance: 2015-12-11

(c) (i)

This article has appeared in the journal Animal

Sentience, a peer-reviewed journal on animal

cognition and feeling. It has been made open access,

free for all, by WellBeing International and deposited

in the WBI Studies Repository. For more information,

please contact

wbisr-info@wellbeingintl.org.

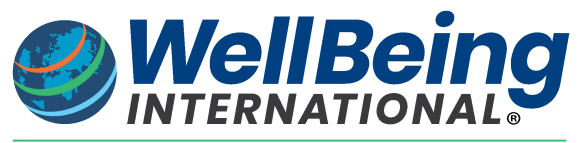

SOLUTIONS FOR PEOPLE, ANIMALS AND ENVIRONMENT 


\title{
No cortex, no cry
}

Commentary on Key on Fish Pain

\author{
Vladimir Dinets \\ Department of Psychology \\ University of Tennessee
}

\begin{abstract}
In his target article, Key (2016) argues that since fish don't have a frontal cortex (part of the brain known to be important for feeling of pain in humans and rodents), they cannot feel pain or other noxious stimuli. I comment on the logic used in this extrapolation and other arguments presented in the paper.
\end{abstract}

Vladimir Dinets dinets@gmail.com is an Assistant Research Professor at the University of Tennessee, Knoxville. He studies behavioral ecology and its applications for conservation. He also enjoys tracking little-known animals in remote parts of the world and writing popular books about biology. http://dinets.info

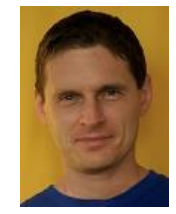

...You despise pain, but I'm sure if you pinch your finger in the door you'll howl at the top of your voice.

Anton Chekhov. Ward No. 6.

Brian Key (2016) opens the target article by arguing that the precautionary principle (i.e., assuming that fish can feel pain just in case it is so) should not be applicable, as it is not evidence-based and can do more harm than good. "Can" is important here because we are talking about possibilities: Key doesn't provide any evidence that fish welfare laws based on the precautionary principle have actually done any harm to any of the potential victims he lists, such as subsistence fishing or economic development. Thus, the author warns us against using the precautionary principle and then uses it himself within the same paragraph.

Then the author lays out his main argument. He suggests that we (1) list the structures responsible for feeling pain in the human brain, (2) check whether these structures are present in fish brains, and (3) consider the result as the definitive evidence of fish being or not being able to feel pain. As support for this leap of logic, he offers studies showing that many brain structures have the same functions in humans and lab rodents, and claims that the same must be true for all other vertebrates.

Overusing the concept of model species has been a staple of modern biology for decades (Futumya, 1998; Greene, 2005), but automatically extrapolating the similarities among some mammals to non-mammalian taxa would lead to outright absurdities such as that crickets are deaf because they don't have human-like ears complete with eardrums; birds can't eat solid food because they lack teeth; and fish cannot move because they don't have legs. 
Virtually all higher brain functions are handled by different structures in mammalian and piscine brains (in mammals pretty much all the important stuff happens in the cerebral cortex, while in all other animals there are other structures in its place): see, for example, Jarvis et al. (2005). The implications of Key's interpretations are not limited to proving the inability of fish to feel pain. It follows that fish are incapable of learning, attention, perception, and awareness, since in mammals the cortex is essential for all these functions (Kandel et al., 2000). It also makes it obvious that the reason for the widespread collapse of commercial fisheries is not overfishing, but the pathetic stupidity of the poor wigglers, too dumb to survive.

Key points out that the fish brain is so simple, even if fish could feel pain, they wouldn't be able to tell which parts of their body the sensations were coming from. Therefore, they wouldn't know what to do about it, and they would silently suffer for no adaptive reason.

This theory also implies that fish cannot tell what part of their body any tactile sensation comes from. Forget all those nature documentaries showing big groupers queuing at "cleaning stations" and opening their mouths to let cleaner wrasses remove parasites from their gums, or moray eels snaking effortlessly through the narrowest cracks in coral reefs without ever getting a scratch. Forget those Youtube videos of pet catfishes flipping over to let their caregivers scratch their bellies. That's all anthropomorphic delusion.

A skeptic might ask: since fish don't have hands and can't scratch a bite or pull out an embedded parasite, their only possible reaction to pain in most cases would be trying to flee, so why would they need to be able to know which part of the body it is coming from? Pain could simply serve to provide a stronger stimulus. But Key is confident that the function of pain in fish must be exactly the same as in humans; hence, if this is impossible, so is any pain in fish.

In the conclusion, Key summarizes his evidence: Fish can't feel pain (or anything, for that matter) because humans use the cerebral cortex for feeling and fish don't have the cerebral cortex. Or, to put it another way, only animals who are intelligent (those with a hypertrophied cerebral cortex) can feel, and fish (like all animals with no hypertrophied cerebral cortex, such as crows, parrots, octopuses, cichlids, and rays) are not sufficiently smart for that; they are just mindless machines.

Why did I mention rays and cichlids? Manta rays apparently can pass the so-called mirror test, which is the universally accepted test for self-awareness and self-recognition (Ari \& D'Agostino, 2014), while almost all mammals, including humans under the age of 18 months and nonhominid primates, cannot (Amsterdam, 1972; Anderson \& Gallup, 2015). Stingrays and cichlids have been documented engaging in play, which is an indication of having complex and flexible behavior (Burghardt, 2014; Burgardt et al., 2014); stingrays are even capable of social learning (Thonhauser et al. 2013) and can invent novel methods of tool use (Kuba et al., 2010). But that's all irrelevant: according to Key, it's only the cortex that counts.

Well, let's use Key's structure-first approach to figure out if fish actually do feel pain. It is really simple. Many animals have specialized neural receptors called noticeptors; their only known 
function is generating signals of pain (see Fein 2012 for a referenced overview). Unless some other function is discovered, their presence must be considered an irrefutable proof that the animal can feel pain. Fish have them (Sneddon et al. 2003). Case closed.

\section{References}

Amsterdam, B. (1972). Mirror self-image reactions before age two. Developmental Psychobiology, 5, 297-305.

Anderson, J. R., \& Gallup, G. G. Jr. (2015). Mirror self-recognition: a review and critique of attempts to promote and engineer self-recognition in primates. Primates, 2015, 1-10. DOI: 10.1007/s10329-015-0488-9.

Ari, C., \& D'Agostino, D. (2014). Contingency checking and self-directed behaviors in giant manta rays: do fish have self-awareness? Abstracts of 2014 American Elasmobranch Society Meeting, Chattanooga, Tennessee.

Burghardt, G. M. (2014). A brief glimpse at the long evolutionary history of play. Animal Behavior \&. Cognition, 1, 90-98. DOI: 10.12966/abc.05.01.2014.

Burghardt, G. M., Dinets, V., \& Murphy, J. B. (2014). Highly repetitive object play in a cichlid fish (Tropheus duboisi). Ethology, 121, 38-44. DOI: 10.1111/eth.12312.

Fein, A. (2012). Nociceptors: the cells that sense pain. http://cell.uchc.edu/pdf/fein/nociceptors fein 2012.pdf

Futumya, D. J. (1998). Wherefore and whither the naturalist? American Naturalist, 151, 1-6. http://www.jstor.org/stable/2463288.

Greene, H.W. (2005) Organisms in nature as a central focus for biology. Trends in Ecology and Evolution, 20, 23-27. DOI: http://dx.doi.org/10.1016/j.tree.2005.04.006

Jarvis, E. D., Güntürkün, O., Bruce, L., Csillag, A., Karten, H., Kuenzel, W., ...Medina, L., Paxinos, G., Perkel, D. J., Shimizu, T., Striedter, G., Wild, M., Ball, G. F., Dugas-Ford, J., Durand, S., Hough, G., Husband, S., Kubikova, L., Lee, D., Mello, C. V., Powers, A., Siang, C., Smulders, T. V., Wada, K., White, S. A., Yamamoto, K., Yu, J., Reiner, A., \& Butler, A. B. (2005). Avian brains and a new understanding of vertebrate brain evolution. Nature Reviews Neuroscience, 6, 151-159. DOI: 10.1038/nrn1606

Kandel, E. R., Schwartz, J. H., \& Jessell, T. M. (2000). Principles of neural science (4 ${ }^{\text {th }}$ Ed.). New York, NY: McGraw-Hill.

Key, B. (2016). Why fish do not feel pain. Animal Sentience 2016.3. 
Kuba, M. J., Byrne, R. A., \& Burghardt, G. M. (2010). A new method for studying problem solving and tool use in stingrays (Potamotrygon castexi). Animal Cognition, 13, 507-513. DOI: 10.1007/s10071-009-0301-5.

Sneddon, L. U., Braithwaite, V. A., \& Gentle, M. J. (2003). Do fishes have nociceptors? Evidence for the evolution of a vertebrate sensory system. Proceedings of the Royal Society of London. Series B. Biological sciences, 270, 1115-1121. DOI:10.1098/rspb.2003.2349

Thonhauser, K. E., Gutnick, T., Byrne, R. A., Kral, K., Burghardt, G. M., \& Kuba, M. J. (2013). Social learning in cartilaginous fish (stingrays Potamotrygon falkneri). Animal Cognition, 16, 927932. DOI: 10.1007/s10071-013-0625-z. 